\title{
Validated RP-HPLC Method for Quantification of Phenolic Compounds in Methanol Extracts of Aerial Parts and Roots of Thymus sipyleus and Evaluation of Antioxidant Potential
}

\author{
Alper Gökbulut \\ Ankara University, Faculty of Pharmacy, Department of Pharmacognosy, 06100, Tandoğan, Ankara, Turkey \\ *For correspondence: Email: gokbulut@pharmacy.ankara.edu.tr; Tel: +903122033106 \\ Received: 2 June 2015 \\ Revised accepted: 7 September 2015
}

\begin{abstract}
Purpose: To evaluate the total phenolic content and antioxidant potential of the methanol extracts of aerial parts and roots of Thymus sipyleus Boiss and also to determine some phenolic compounds using a newly developed and validated reversed phase high performance liquid chromatography (RP-HPLC) method.

Methods: The total phenolic concentration of the extracts were determined using Folin Ciocalteu method. The antioxidative potential of the samples was evaluated using DPPH and ABTS assays. Phenolics responsible for the antioxidant activity of the plant were quantified by a newly developed and validated RP-HPLC method for the first time.

Results: The total phenolic concentration of the aerial parts and roots were $215.1 \pm 2.24$ and $152.25 \pm$ $2.31 \mathrm{mg} \mathrm{GAE} / \mathrm{g}$ extracts, respectively. The extract obtained from the aerial parts reduced DPPH with a half-maximal inhibition concentration $\left(I C_{50}\right)$ of $0.703 \pm 0.027 \mathrm{mg} / \mathrm{mL}$, while the $I C_{50}$ obtained from ABTS assay was $0.869 \pm 0.066 \mathrm{mg} / \mathrm{mL}$. IC 50 values of Trolox used as standard for DPPH and ABTS radical scavenging assays were $0.0430 \pm 0.0001$ and $0.0420 \pm 0.0001 \mathrm{mg} / \mathrm{mL}$, respectively. The results revealed that $T$. sipyleus contains remarkable amounts of rosmarinic acid in the aerial parts $(0.8887 \pm$ $0.0016 \mathrm{~g} / 100 \mathrm{~g} \mathrm{dw})$ and in the roots $(0.3454 \pm 0.0006 \mathrm{~g} / 100 \mathrm{~g} \mathrm{dw})$ which is believed to be mostly responsible for the observed activity.

Conclusion: T. sipyleus is a major potential antioxidant source for the food, pharmaceutical and cosmetic industry due to its high contents of rosmarinic acid and total phenolics.
\end{abstract}

Keywords: Thymus sipyleus, Rosmarinic acid, Chlorogenic acid, Caffeic acid, Apigenin, Antioxidant

Tropical Journal of Pharmaceutical Research is indexed by Science Citation Index (SciSearch), Scopus, International Pharmaceutical Abstract, Chemical Abstracts, Embase, Index Copernicus, EBSCO, African Index Medicus, JournalSeek, Journal Citation Reports/Science Edition, Directory of Open Access Journals (DOAJ), African Journal Online, Bioline International, Open-J-Gate and Pharmacy Abstracts

\section{INTRODUCTION}

Plants are valuable sources of natural compounds with different chemical and biological properties. Plant secondary metabolites and extracts are of great interest during the last few decades due to their various pharmacological activities. The wide usage of plants as food, food additives, health promoting agents and supplements has undoubtedly increased the number of studies which aim to set light to the chemical composition and biological activity of these sources [1-3].

Oxidative stress which can be defined as the imbalance between oxidants and antioxidants, elicit several pathophysiological disorders such as cancer, aging and other diseases. It's clear that fighting with these parameters plays an important role in the prevention of chronic diseases. It is very important to consider plants first in order to eliminate the risk of such 
disorders. Numerous crude extracts and natural compounds have been reported to have antioxidant and radical scavenging properties [35]. Phenolic compounds like flavonoids, tannins, caffeic acid derivatives are known to be the potential antioxidants of the natural sources [2].

The Lamiaceae family is a good source of aromatic and spicy plants that have a strong antioxidant potential. Many of the aromatic plants of the Lamiaceae family grow wild in Mediterranean region. Rosmarinus, Salvia and Thymus species are the primary members of the Lamiaceae family. Among these, the members of Thymus species are very popular for their carminative, expectorant, antitussive and antioxidant characteristics and are widely used as spices, herbal teas and flavoring agents all over the World $[2,6]$. It has been known that there is an inverse relationship between dietary intake of antioxidant-rich foods and the incidence of a number of human diseases [7,8]. Also, natural sources like fresh and dried aromatic plants as well as their processed products have been widely used as flavouring agents for centuries. The antioxidant potential of these sources could be evaluated to extend the life span of foods and nutraceuticals that are displayed on shelf. Therefore, it is important to research into the determination of natural antioxidant sources.

The genus Thymus is one of the largest member of the Lamiaceae family and is represented by 39 species with 64 taxa in Turkey [9]. Thymus sipyleus is known as "kekik otu" and is used as a spice in Turkey [10]. Most previous studies have focused primarily on the essential oil composition of numerous Thymus taxa [11-17]. Using a different approach, this paper reports the qualitative and quantitative analysis of phenolics in different parts of Thymus sipyleus for the first time, together with antioxidant activity and total phenolic content.

\section{EXPERIMENTAL}

\section{Chemicals}

Chromatographic grade double-distilled water, HPLC grade methanol, acetonitrile and analytical grade trifluoroacetic acid were used for HPLC analysis. Folin Ciocalteu reagent and the following phenolic compounds were purchased from Sigma (Germany): rosmarinic acid (536954), chlorogenic acid (C3878), caffeic acid (C0625) and apigenin (10798). Also, DPPH (D9132) and ABTS (A1888) were purchased from Sigma (Germany). All other chemicals were of analytical grade and obtained from either
Sigma (Germany) or Merck (Darmstadt, Germany).

\section{Materials}

Thymus sipyleus Boiss. was collected from Kıbrısköyü, Ankara during its flowering period in July. The voucher specimen was deposited in the Herbarium of the Ankara University, Faculty of Pharmacy (AEF 26639).

\section{Extraction procedure}

For the total phenolic content and antioxidant activity tests, $5 \mathrm{~g}$ of air dried and milled aerial parts and roots of the plant were extracted with methanol ( $\geq 99.9 \%, 100 \mathrm{~mL})$ using a magnetic stirrer for $1 \mathrm{~h}\left(50^{\circ} \mathrm{C}, 250 \mathrm{rpm}\right)$. After filtration, methanol was evaporated completely in a rotary evaporator (Buchi-R200). The dry crude extracts were used for antioxidant activity and total phenolic content assays.

For the HPLC analysis, $200 \mathrm{mg}$ of air dried and milled aerial parts and roots were extracted with methanol ( $\geq 99.9 \%)$, using a magnetic stirrer, for $6 \mathrm{~h}\left(50{ }^{\circ} \mathrm{C}, 250 \mathrm{rpm}\right)$. The extracts were then filtered, made up to $10.0 \mathrm{~mL}$ in a volumetric flask with methanol, passed through a $0.45 \mu \mathrm{m}$ filter, and injected into the HPLC system.

\section{Determination of total phenolic content}

The total phenolic content of the extracts was determined spectrophotometrically using a modified Folin Ciocalteu method [18]. The reduction of the reagent, which resulted in the formation of a blue colour, was recorded at 765 $\mathrm{nm}$. One hundred $\mu \mathrm{L}$ of the methanol extract of each plant part $(2 \mathrm{mg} / \mathrm{mL})$ was mixed with $7.9 \mathrm{~mL}$ of distilled water. Folin Ciocalteu reagent (500 $\mu \mathrm{L}$ ) was added and the contents of the flask were vortexed. After $8 \mathrm{~min}, 1.5 \mathrm{~mL}$ of $20 \% \mathrm{Na}_{2} \mathrm{CO}_{3}$ was added. After $2 \mathrm{~h}$ of incubation at room temperature, the absorbance was measured at $765 \mathrm{~nm}$ using a Shimadzu spectrometer. Gallic acid was used as the standard. All measurements were performed in triplicate, and the average values were used to express the $\mathrm{mg}$ of gallic acid equivalents (GAE)/g dry extract.

\section{1,1-Diphenyl-2-picrylhydrazyl) radical scavenging activity (DPPH) assay}

The capacity to scavenge the stable free radical DPPH was monitored according to the modified method of Barros et al. [19]. An aliquot of each extract $(0.25 \mathrm{~mL})$ was mixed with $2.75 \mathrm{~mL}$ of the methanolic solution containing DPPH radical. The mixture was shaken vigorously and left to 
stand for $10 \mathrm{~min}$ in the dark (until stable absorption values were obtained). The reduction of the DPPH radical was determined by measuring the absorption at $517 \mathrm{~nm}$. The radical scavenging activity (D) was calculated as a percentage of DPPH discoloration as in Eq 1.

$D(\%)=\{(\mathrm{Ab}-\mathrm{As}) / \mathrm{Ab}\} 100$

where As is the absorbance of the solution when the sample extract was added at a particular level, and $A b$ is the absorbance of the $\mathrm{DPPH}$ solution. The extract concentration providing 50 $\%$ inhibition $\left(\mathrm{IC}_{50}\right)$ was calculated from the graph of inhibition percentage against the extract concentration. Trolox (Sigma, Germany) and caffeic acid were used as the standard.

\section{2,2'-Azino-bis(3-ethylbenzthiazoline-6- sulphonic acid) (ABTS) assay}

ABTS radical scavenging activity was measured using a modification of the method of Re et al [20]. ABTS was dissolved in methanol to a concentration of $7 \mathrm{mM}$. ABTS radical cation was produced by reaction of ABTS stock solution with $2.45 \mathrm{mM} \mathrm{K}_{2} \mathrm{~S}_{2} \mathrm{O}_{8}$ (as an oxidant for conversion of ABTS into a radical cation). The color of the resulting solution was blue-green. This radical solution was kept in the dark at room temperature for 12 - $16 \mathrm{~h}$ before use in precise measurements. The ABTS radical cation solution was diluted with $96 \%$ ethanol to obtain an absorbance of $0.70 \pm 0.02$ at $734 \mathrm{~nm}$. An aliquot of each extract $(0.25 \mathrm{~mL})$ was mixed with 2.75 $\mathrm{mL}$ of diluted ABTS radical cation solution. After the reaction at room temperature for $6 \mathrm{~min}$, the reduction in absorbance at $734 \mathrm{~nm}$ was measured. The radical scavenging activity (B) was calculated as a percentage of ABTS inhibition as in Eq 2.

$B(\%)=\{(A b-A s) / A b\} 100$

where As is the absorbance of the solution when the sample extract was added at a particular level, and $A b$ is the absorbance of the ABTS solution. The extract concentration providing 50 $\%$ inhibition $\left(\mathrm{IC}_{50}\right)$ was calculated from the graph of inhibition percentage against extract concentration. Trolox (Sigma, Germany) was used as the standard.

\section{Identification and quantification of phenolic compounds by HPLC-DAD}

The qualitative and quantitative analyses of the phenolic compounds in the extracts were performed according to the following procedure. The analysis was performed with a LC system consisting of a HP Agilent 1260 series quaternary pump, de-gasser and photo-diode array detector. The samples were injected into a HP Agilent 1260 Autosampler with a thermostated column compartment on an ACE column $(5 \mu, 250 \mathrm{~mm} \times 4.6 \mathrm{~mm})$ at $30{ }^{\circ} \mathrm{C}$. The system was controlled and data analysis was performed using Agilent ChemStation software. All the calculations concerning the quantitative analysis were performed with external standardization by measurement of the peak areas. Gradient elution was applied with a flow rate of $0.8 \mathrm{~mL} / \mathrm{min}$ and column temperature was set to $30{ }^{\circ} \mathrm{C}$. The mobile phase was a mixture of trifluoroacetic acid $0.1 \%$ in water (solution $\mathrm{A}$ ), trifluoroacetic acid $0.1 \%$ in methanol (solution B), and trifluoroacetic acid $0.1 \%$ in acetonitrile (solution $\mathrm{C}$ ).

The composition of the gradient was $(A: B: C)$, $80: 12: 8$ at $0 \mathrm{~min}, 75: 15: 10$ at $8 \mathrm{~min}, 70: 18: 12$ at $16 \mathrm{~min}, 65: 20: 15$ at $24 \mathrm{~min}, 50: 35: 15$ at $32 \mathrm{~min}$, $25: 60: 15$ at $40 \mathrm{~min}$ and $80: 12: 8$ at $45 \mathrm{~min}$. The duration between the runs was $2 \mathrm{~min}$. All the solvents were filtered through a $0.45 \mu \mathrm{m}$ millipore filter before use and de-gassed was in an ultrasonic bath. From each solution and sample, $10 \mu \mathrm{L}$ was injected into the column and the chromatograms were recorded from 200 to 400 $\mathrm{nm}$. Standard solutions were analyzed and threedimensional chromatograms (wavelength; time; absorbance) were obtained to select the optimum wavelength for detection of the phenolics with maximum sensitivity. Quantification was performed by measuring all the investigated phenolics at $330 \mathrm{~nm}$ using a photo-diode array detector. The chromatographic run time was $45 \mathrm{~min}$.

\section{Calibration}

Five different concentrations of rosmarinic acid, chlorogenic acid, caffeic acid and apigenin were prepared in methanol ranging between 4.3-215 $\mu \mathrm{g} / \mathrm{mL}, 5-250 \mu \mathrm{g} / \mathrm{mL}, 5.2-260 \mu \mathrm{g} / \mathrm{mL}$ and 2-100 $\mu \mathrm{g} / \mathrm{mL}$, respectively. $10 \mu \mathrm{L}$ of triplicate was injected into each standard solution to see the reproducibility of the detector response at each concentration level. The peak areas obtained from the injections were plotted against the concentrations to establish the calibration graph.

\section{Limits of detection and quantification}

The limits of detection (LOD) were established at a signal to noise ratio $(\mathrm{S} / \mathrm{N})$ of 3 . The limits of quantification (LOQ) were established at a signal to noise ratio $(\mathrm{S} / \mathrm{N})$ of 10 . LOD and $L O Q$ were experimentally verified by the nine injections of reference compounds in LOQ concentrations. 


\section{Precision}

The precision of the method (within-day variations of replicate determinations) was checked by injecting reference compounds nine times at the LOQ levels. The area values were recorded and RSD\% was calculated.

\section{Recovery}

Spike recovery was carried out by the standard addition method. For the determination of the recovery from the methanol extract, three different concentrations of reference compounds were added prior to the extraction. In each additional level, six determinations were carried out and the mean value of recovery percentage was calculated.

\section{RESULTS}

\section{Total phenolic content}

The extract yields of aerial parts and roots of $T$. sipyleus were determined as 7.62 and $4.17 \%$ $(w / w)$, respectively. The phenol content of aerial parts and roots were $215.1 \pm 2.24$ and $152.25 \pm$ $2.31 \mathrm{mg} \mathrm{GAE} / \mathrm{g}$ extract, respectively.

\section{DPPH (1,1-diphenyl-2-picrylhydrazyl) radical scavenging activity}

The extract obtained from the aerial parts of $T$. sipyleus was able to reduce the stable free radical DPPH to the yellow-colored diphenylpicrylhydrazine with an $\mathrm{IC}_{50}$ of $0.703 \pm$ $0.027 \mathrm{mg} / \mathrm{mL}$, showing better activity than the root extract $(1.325 \pm 0.035 \mathrm{mg} / \mathrm{mL})$. A high amount of the total phenolic content determined in the aerial parts of the plant resulted in a better radical scavenging activity compared to the root. Both the aerial part and the root extracts of $T$. sipyleus exhibited lower antioxidant potential, with higher $\mathrm{IC}_{50}$ values than Trolox $(0.043 \pm$ $0.0001 \mathrm{mg} / \mathrm{mL})$ and caffeic acid $(0.052 \pm 0.0001$ $\mathrm{mg} / \mathrm{mL}$ ).

\section{ABTS [2,2'-azino-bis(3-ethylbenzthiazoline-6- sulphonic acid)] assay}

The ABTS assay results were found to be in parallel with the DPPH radical scavenging activity results. Similarly, the methanol extract obtained from the aerial parts exhibited stronger activity $\left(\mathrm{IC}_{50}: 0.869 \pm 0.066 \mathrm{mg} / \mathrm{mL}\right)$ than the root extract $\left(\mathrm{IC}_{50}: 1.504 \pm 0.06 \mathrm{mg} / \mathrm{mL}\right)$ with regard to the higher amount of total phenolics. Both the aerial part and the root extracts of $T$. sipyleus exhibited lower antioxidant potential with higher $I C_{50}$ values than Trolox $(0.042 \pm 0.0001 \mathrm{mg} / \mathrm{mL})$.

\section{Identification and quantification of phenolic compounds by HPLC-DAD}

As can be seen from the chromatograms obtained from both extracts, the major compound of $T$. sipyleus is rosmarinic acid (Figure 1, 2).

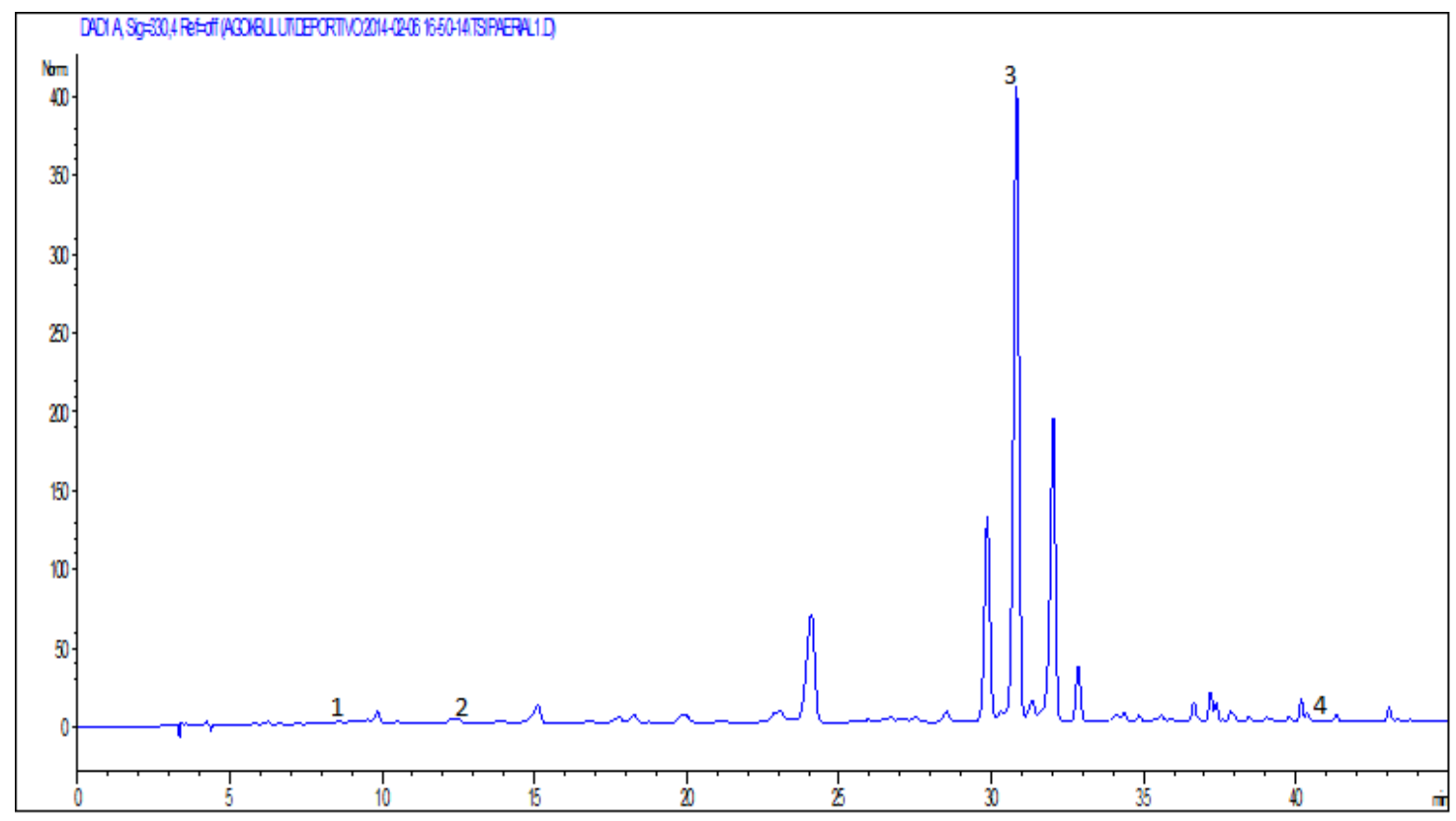

Figure 1: HPLC chromatogram of $T$. sipyleus aerial part. 1, chlorogenic acid; 2, caffeic acid; 3, rosmarinic acid; 4, apigenin 


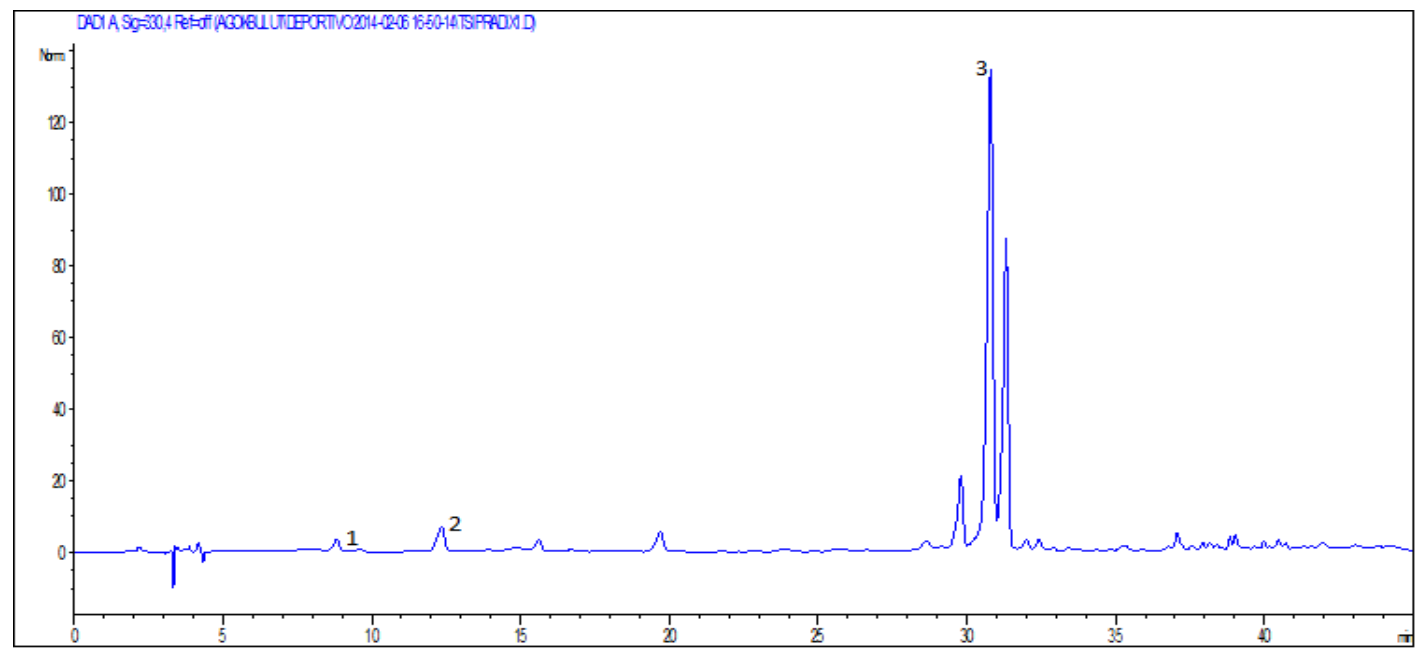

Figure 2: HPLC chromatogram of $T$. sipyleus root. 1, chlorogenic acid; 2, caffeic acid; 3, rosmarinic acid

In approximately 40 min, chlorogenic acid, caffeic acid, rosmarinic acid and apigenin were detected and quantified after evaluating the retention times and UV spectra of the phenolic compounds. For instance, the UV spectra of authentic rosmarinic acid, rosmarinic acid in the aerial parts and rosmarinic acid in the roots were overlaid and all the spectra fit wonderfully. The method was validated and fine results were obtained. The precision of the method was checked by injecting chlorogenic acid, caffeic acid, rosmarinic acid and apigenin nine times at the LOQ levels and was expressed as RSD\%: 1.7809, 1.9409, 1.9487 and 1.8126, respectively. Retention times, linear relationships between peak areas and concentrations, test ranges, LOD and $L O Q$ values are given in Table 1. No other effect was determined as it was ensured by the recovery values given in Table 2 . The contents of phenolic compounds in different parts of $T$. sipyleus are given in Table 3. Rosmarinic acid, the major compound, was determined in the aerial parts as $0.8887 \pm 0.0016 \mathrm{~g} / 100 \mathrm{~g} \mathrm{dw}$ and in the roots as $0.3454 \pm 0.0006 \mathrm{~g} / 100 \mathrm{~g} \mathrm{dw}$. The occurrence of more antioxidant activity of the aerial parts could be explained to have resulted from the higher rosmarinic acid content.

\section{DISCUSSION}

It is obvious that the antioxidant capacity of the $T$. sipyleus extracts is associated with the presence of phenolic compounds, especially the rosmarinic acid. Rosmarinic acid is an ester of 3,4-dihydroxyphenyllactic acid and caffeic acid. Boraginaceae and the sub-family Nepetoideae of the Lamiaceae, generally contain this highly antioxidant compound which renders a number of interesting biological functions, e.g. antiviral, antibacterial, anti-inflammatory and antioxidant. The presence of rosmarinic acid in medicinal plants, herbs and spices have beneficial and health promoting effects.

Rosmarinic acid and rosmarinic acid hydrolyzed phenolics are very important, maintaining the stability and protection of tissue membranes and proteins from free radical damage. Herb extracts containing rosmarinic acid have widely been used for functional food and pharmacological procedures [21,22]. For this reason qualitative and quantitative analysis of such compounds are getting more important. In the present study, a simple, low-cost and sensitive RP-HPLC method was developed and validated to quantify

Table 1: Retention times, linear relationships between peak areas and concentrations, test ranges, LOD and LOQ

\begin{tabular}{lcccccc}
\hline Analyte & $\begin{array}{c}\text { Retention } \\
\text { time (min) }\end{array}$ & Standard curve & $\mathbf{r}$ & $\begin{array}{c}\text { Test range } \\
(\mu \mathbf{\mu g} / \mathbf{m L})\end{array}$ & $\begin{array}{c}\mathbf{L O D}^{\mathrm{a}} \\
(\boldsymbol{\mu} \mathbf{g} / \mathbf{m L})\end{array}$ & $\begin{array}{c}\mathbf{L O Q}^{\mathbf{b}} \\
(\boldsymbol{\mu g} / \mathbf{m L})\end{array}$ \\
\hline Chlorogenic acid & 8.8 & $y=22083 x-6.4807$ & 0.9999 & $0.37-500$ & 0.11 & 0.37 \\
Caffeic acid & 12.3 & $y=56891 x+30.81$ & 0.9996 & $0.07-520$ & 0.02 & 0.07 \\
Rosmarinic acid & 30.8 & $y=28820 x-26.234$ & 0.9999 & $0.24-1030$ & 0.07 & 0.24 \\
Apigenin & 40.3 & $y=49866 x+28.995$ & 0.9993 & $0.07-200$ & 0.02 & 0.07 \\
\hline
\end{tabular}

$y$, peak area; $x$, concentration of analyte $(\mathrm{mg} / \mathrm{mL}) ;{ }^{2} L O D=$ limit of detection $S / \mathrm{N}: 3(n=9) ;{ }^{b} L O Q=$ limit of quantification $\mathrm{S} / \mathrm{N}: 10(n=9)$ 
Table 2: Recovery values for the quantified compounds

\begin{tabular}{|c|c|c|c|c|c|c|}
\hline \multirow[b]{2}{*}{ Compound } & \multirow{2}{*}{$\begin{array}{c}\text { Initial } \\
\text { concentratio } \\
\mathrm{n} \text { in the } \\
\text { extract } \\
(\mu \mathrm{g} / \mathrm{mL})\end{array}$} & \multirow{2}{*}{$\begin{array}{c}\text { Amount } \\
\text { added }(\mu \mathrm{g})\end{array}$} & \multicolumn{2}{|c|}{$\begin{array}{c}\text { Concentration after addition } \\
(\mu \mathrm{g} / \mathrm{mL})\end{array}$} & \multirow[b]{2}{*}{$\begin{array}{c}\text { Recovery } \\
(\%)\end{array}$} & \multirow[b]{2}{*}{$\operatorname{RSD}^{\mathrm{a}}(\%)$} \\
\hline & & & Expected & Measured & & \\
\hline \multirow{4}{*}{$\begin{array}{l}\text { Chlorogenic } \\
\text { acid }\end{array}$} & 1.037 & 20 & 21,037 & 20.84 & 99,06 & 3.14 \\
\hline & 1.039 & 3.125 & 4.164 & 4.399 & 105.64 & 2.31 \\
\hline & 1.039 & 1.05 & 2.089 & 2.064 & 98.8 & 1.04 \\
\hline & 0.058 & 26 & 26.058 & 24.296 & 93.23 & 0.89 \\
\hline \multirow[t]{2}{*}{ Caffeic acid } & 0.058 & 4.25 & 4.308 & 4.289 & 99.56 & 5.55 \\
\hline & 0.058 & 1.25 & 1.308 & 1.212 & 92.66 & 6.72 \\
\hline \multirow{4}{*}{$\begin{array}{l}\text { Rosmarinic } \\
\text { acid }\end{array}$} & 179.069 & 21.5 & 200.569 & 181.13 & 90.3 & 1.32 \\
\hline & 179.51 & 5.375 & 184.885 & 173.85 & 94.01 & 1.21 \\
\hline & 179.51 & 2.15 & 181.66 & 184.83 & 101.74 & 0.70 \\
\hline & 0.189 & 8.5 & 8.689 & 8.93 & 102.77 & 0.18 \\
\hline \multirow[t]{2}{*}{ Apigenin } & 0.190 & 2.38 & 2.57 & 2.403 & 93.5 & 0.59 \\
\hline & 0.190 & 0.85 & 1.04 & 0.964 & 92,69 & 2.58 \\
\hline
\end{tabular}

${ }^{\mathrm{a}} \mathrm{RSD}=$ relative standard deviation

Table 3: The contents of phenolic compounds in the aerial parts and roots of $T$. Sipyleus

\begin{tabular}{lcccc}
\hline \multirow{2}{*}{ Plant part } & \multicolumn{4}{c}{ Content (g/100g dryweight) } \\
& Chlorogenic acid & Caffeic acid & Rosmarinic acid & Apigenin \\
\hline Aerial parts & $0.0051 \pm 0.0002$ & $0.0003 \pm 0.0001$ & $0.8887 \pm 0.0016$ & $0.0009 \pm 0.0001$ \\
Roots & $0.0118 \pm 0.0002$ & $0.0083 \pm 0.0001$ & $0.3454 \pm 0.0006$ & nd $^{\mathrm{b}}$ \\
\hline${ }^{a}$ mean $\pm S D(n=3) ;{ }^{b}$ nd $=$ not detected & & &
\end{tabular}

rosmarinic acid as well as caffeic acid, chlorogenic acid, and apigenin in $T$. sipyleus aerial parts and roots. During the method development, mobile phase components and ratios, flow rate, column temperature and column type were changed to find out the optimum state for the best separation. To present the gradient system, different combinations of water $(A)$, methanol $(B)$ and acetonitrile $(C)$ each containing $0.1 \%$ TFA were attempted. The gradient system in the ratio of $A: B: C, 80: 12: 8$ at $0 \mathrm{~min}, 75: 15: 10$ at $8 \mathrm{~min}, 70: 18: 12$ at $16 \mathrm{~min}, 65: 20: 15$ at $24 \mathrm{~min}$, $50: 35: 15$ at $32 \mathrm{~min}, 25: 60: 15$ at $40 \mathrm{~min}$ and $80: 12: 8$ at $45 \mathrm{~min}$, achieved the best separation and was chosen as the gradient solvent system. ACE C18 column $(5 \mu, 250 \mathrm{~mm} \times 4.6 \mathrm{~mm})$ which is an efficient preference for separation of polar compounds, was used. To eliminate the deviation with regards to temperature differentiation, column temperature was controlled and set to $30{ }^{\circ} \mathrm{C}$. The flow rate was arranged to $0.8 \mathrm{~mL} / \mathrm{min}$ after trials of different flows.

\section{CONCLUSION}

This work reports the development of a simple, low-cost and sensitive RP-HPLC method for the determination of phenolics of $T$. sipyleus together with the antioxidant activity and total phenolic content. This newly developed and validated RPHPLC-DAD method will help researchers to determine the phenolic compounds of other natural sources. Furthermore, the significant rosmarinic acid and total phenolics content of $T$. sipyleus is probably responsible for the high radical scavenging activities of $T$. sipyleus, thus making the plant a potentially good source of antioxidants for the food, pharmaceutical and cosmetic industries.

\section{ACKNOWLEDGEMENT}

The author wishes to thank Prof Dr Zeki AYTAÇ for the identification of the plant used in this work.

\section{REFERENCES}

1. Blumenthal M. The $A B C$ clinical guide to herbs. New York: Thieme; 2003.

2. Bruneton J. Pharmacognosy, phytochemistry, medicinal plants. 2nd ed. Paris: Intercept Ltd; 1999. 545p.

3. Loziene K, Venskutonis PR, Sipailiene A, Labokas J. Radical scavenging and antibacterial properties of the extracts from different Thymus pulegioides $L$. chemotypes. Food Chem 2007; 103: 546-559.

4. Gokbulut A, Ozhan O, Satilmis B, Batcioglu K, Gunal S, Sarer E. Antioxidant and antimicrobial activities, and phenolic compounds of selected Inula species from Turkey. Nat Prod Commun 2013; 8: 475-478.

5. Ozgen U, Mavi A, Terzi Z, Kazaz C, Asci A, Kaya $Y$, Secen $H$. Relationship between chemical structure and antioxidant activity of luteolin and its glycosides 
isolated from Thymus sipyleus subsp sipyleus var. sipyleus. Rec Nat Prod 2011; 5: 12-21.

6. Kucukbay FZ, Kuyumcu E, Celen S, Azaz AD, Arabaci T. Chemical composition of the essential oils of three Thymus taxa from Turkey with antimicrobial and antioxidant activities. Rec Nat Prod 2014; 8: 110-120.

7. Miller NJ, Rice-Evans CA. Factors influencing the antioxidant activity determined by the ABTS (+) radical cation assay. Free Radical Res 1997; 26: 195199.

8. $L u Y$, Foo $L Y$. Antioxidant and radical scavenging activities of polyphenols from apple pomace. Food Chem 2000; 68: 81-85.

9. Davis PH. Flora of Turkey and the East Aegean Islands. Edinburgh: Edinburgh University Press; 1982. $p$. 349-382.

10. Ozgen U, Mavi A, Terzi Z, Yildirim A, Coskun M, Houghton PJ. Antioxidant properties of some medicinal Lamiaceae (Labiatae) species. Pharm Biol 2006; 44: 107-112.

11. Bounatirou S, Smiti S, Miguel MG, Faleiro L, Rejeb MN, Neffati $M$, Costa MM, Figueiredo AC, Barroso JG, Pedro LG. Chemical composition, antioxidant and antibacterial activities of the essential oils isolated from Tunisian Thymus capitatus Hoff. et Link. Food Chem 2007; 105: 146-155.

12. Cosentino S, Tuberoso CIG, Pisano B, Satta M, Mascia $V$, Arzedi E, Palmas F. In-vitro antimicrobial activity and chemical composition of Sardinian Thymus essential oils. Lett Appl Microbiol 1999; 29: 130-135.

13. Miguel G, Simoes M, Figueiredo AC, Barroso JG, Pedro LG, Carvalho L. Composition and antioxidant activities of essential oils of Thymus caespititius, Thymus camphoratus and Thymus mastichina. Food Chem 2004; 86: 183-188.

14. Rota MC, Herrera A, Martinez RM, Sotomayor JA, Jordan MC. Antimicrobial activity and chemical composition of Thymus vulgaris, Thymus zygis and Thymus hyemalis essential oils. Food Control 2008; 19: 681 687.

15. Salgueiro LR, Vila R, Tomi F, Figueiredo AC, Barroso JG, Canigueral S, Casanova J, Proenca da Cunha A, Adzet T. Variability of essential oils of Thymus caespititius from Portugal. Phytochemistry 1997; 45: 307-311.

16. Sokmen A, Gulluce M, Akpulat HA, Daferera D, Tepe B, Polissiou $M$, Sokmen $M$, Sahin $F$. The in vitro antimicrobial and antioxidant activities of the essential oils and methanol extracts of endemic Thymus spathulifolius. Food Control 2004; 15: 627-634.

17. Tepe B, Sokmen M, Akpulat HA, Daferera D, Polissiou M, Sokmen A. Antioxidative activity of the essential oils of Thymus sipyleus subsp. sipyleus var. sipyleus and Thymus sipyleus subsp. sipyleus var. rosulans. J Food Eng 2005; 66: 447-454.

18. Singleton VL, Orthofer $R$, Lamuela-Raventos RM. Analysis of total phenols and other oxidation substrates and antioxidants by means of FolinCiocalteu reagent. Method Enzymol 1999; 299: 15278.

19. Barros L, Baptista P, Ferreira ICFR. Effect of Lactarius piperatus fruiting body maturity stage on antioxidant activity measured by several biochemical assays. Food Chem Toxicol 2007; 45: 1731-1737.

20. Re R, Pellegrin N, Proteggente A, Pannala A, Yang M, Rice-Evans C. Antioxidant activity applying an improved ABTS radical cation decolorization assay. Free Radical Bio Med 1999; 26: 1231-1237.

21. Shetty K, Paliyath G, Pometto A, Levin RE. Food biotechnology. 2nd ed. Boca Raton: CRC press; 2006. p. 825-845.

22. Petersen $M$, Abdullah $Y$, Benner J, Eberle $D$, Gehlen $K$, Hucherig S, Janiak V, Kim KH, Sander M, Weitzel C, Wolters $S$. Evolution of rosmarinic acid biosynthesis. Phytochemistry 2009; 70: 1663-1679. 